\title{
DEVELOPMENT OF AN AUTOMATED BENCH TOP ELECTRONIC PENETROMETER
}

\section{ALOÍSIO BIANCHINI ${ }^{1}$, MÁRCIO W. ROQUE ${ }^{2}$, RODRIGO P. ROSA ${ }^{3}$}

\begin{abstract}
The aim of this study was to develop a an automated bench top electronic penetrometer (ABEP) that allows performing tests with high rate of data acquisition (up to 19,600 $\mathrm{Hz}$ ) and with variation of the displacement velocity and of the base area of cone penetration. The mechanical components of the ABEP are: a supporting structure, stepper motor, velocity reducer, double nut ball screw and six penetration probes. The electronic components of ABEP are: a "driver" to control rotation and displacement, power supply, three load cells, two software programs for running and storing data, and a data acquisition module. This penetrometer presented in compact size, portable and in 32 validation tests it proved easy to operate, and showed high resolution, high velocity in reliability in data collection. During the validation tests the equipment met the objectives, because the test results showed that the ABEP could use different sizes of cones, allowed work at different velocities, showed for velocity and displacement, were only $1.3 \%$ and $0.7 \%$, respectively, at the highest velocity (30 $\mathrm{mm} \mathrm{s}-1)$ and $1 \%$ and $0.9 \%$, respectively for the lowest velocity $(0.1 \mathrm{~mm} \mathrm{~s}-1)$.
\end{abstract}

KEYWORDS: soil compaction, soil resistance to penetration, velocity test, cone index.

\section{DESENVOLVIMENTO DE UM PENETROGRAFO ELETRÔNICO AUTOMÁTICO DE BANCADA}

RESUMO: O objetivo deste trabalho foi desenvolver um penetrógrafo eletrônico automático de bancada (PEAB) que permita realizar ensaios com alta taxa de aquisição de dados (até $19.600 \mathrm{~Hz}$ ) e com variação da velocidade de deslocamento e da área da base do cone de penetração. Os componentes mecânicos do PEAB são uma estrutura de sustentação; motor de passo; redutor de velocidade; fuso de esferas com castanha dupla e seis sondas de penetração. Os componentes eletroeletrônicos que fazem parte do PEAB são um "driver", para controle de rotação e deslocamento; fonte de alimentação; três células de carga; dois softwares para execução e armazenamento de dados, e um módulo de obtenção de dados. O penetrógrafo apresentou tamanho compacto, portabilidade e, em 32 ensaios de validação, mostrou-se de fácil operação, elevada resolução, rapidez e confiabilidade na obtenção dos dados. O equipamento atendeu aos objetivos propostos, pois os resultados dos ensaios permitiram observar que o PEAB comporta diferentes tamanhos de cone e possibilitou trabalhar com diferentes velocidades, sendo as incertezas para velocidade e deslocamento, respectivamente, de apenas $1,3 \%$ e $0,7 \%$ na velocidade mais alta (30 $\mathrm{mm} \mathrm{s}-1)$ e de $1 \%$ e $0,9 \%$ na velocidade mais baixa $(0,1 \mathrm{~mm} \mathrm{~s}-1)$.

PALAVRAS-CHAVE: compactação de solo, RSP, velocidade de ensaio, índice de cone.

\section{INTRODUCTION}

The agricultural mechanization allows the production of different crops in the same area, but the intensive traffic of machines in the field has brought many problems including soil compaction. According to COLLARES et al. (2006), soil compaction is the reorganization of the particles and aggregates, which the density of the soil, reduces macroporosity, and inhibits the growth and root

\footnotetext{
${ }^{1}$ Professor Associado, Departamento de Solos e Engenharia Rural, Universidade Federal de Mato Grosso, e-mail bianchi@ufmt.br.

${ }^{2}$ Eng Agrícola, Professor do Departamento de Solos e Engenharia Rural da Faculdade de Agronomia, Medicina Veterinária e

Zootecnia da UFMT, roque@ufmt.br.

${ }^{3}$ Mestrando em Agricultura Tropical pela Universidade Federal de Mato Grosso, rodrigopengo@hotmail.com.

Recebido pelo Conselho Editorial em: 25-2-2013
}

Aprovado pelo Conselho Editorial em: 3-7-2013 
development of the plants. However, the crop response to the presence of the compacted soil layer is not yet fully known (COLLARES et al., 2008).

The soil resistance to penetration is a mechanical attribute and can be used as an indication of compaction, and according to SILVA (2003) is more efficient in identifying layers of compacted soils when compared to the soil density. The equipment used for the determination of the resistance to penetration known as the penetrometers, and literature have cited various models of these devices, which were used with different operating modes, making it difficult to compare the results obtained by different authors. BERGAMIN et al. (2010) and GELAIN et al. (2011) used an electronic penetrometer developed by SERAFIM et al. (2008), with a constant velocity of penetration of $0.1667 \mathrm{~mm} \mathrm{~s}^{-1}$, a base area of the cone of $12.56 \mathrm{~mm}^{2}$, and a $60^{\circ}$ angle. The study developed by BEUTLER et al. (2007) used a laboratory static electronic penetrometer with a constant velocity of penetration of $0.1667 \mathrm{~mm} \mathrm{~s}^{-1}$ and a base area of the cone (BAC) of $3.7 \mathrm{~mm}^{2}$.

The bench top penetrometer used by PACHECO (2010) and PACHECO \& CATALICE (2011), of the Marconi ${ }^{\circledR}$ brand, was equipped with a load cell containing a rod with a BAC of 12.56 $\mathrm{mm}$, a cone angle of $45^{\circ}$ and penetration velocity of $0.1667 \mathrm{~mm} \mathrm{~s}^{-1}$. CARMO et al. (2011) used a bench top penetrometer of the same brand, model MA-933, and worked with a cone with a BAC of $19.68 \mathrm{~mm}^{2}$, an angle of $45^{\circ}$, and a constant velocity of $2 \mathrm{~mm} \mathrm{~s}^{-1}$. KLEIN \& CAMARA (2007) used a model MA-933 as well, at a constant velocity of $0.1667 \mathrm{~mm} \mathrm{~s}^{-1}$, equipped with a load cell of $200 \mathrm{~N}$, a and cone with a BAC of $12.56 \mathrm{~mm}^{2}$ of base area, and a $60^{\circ}$ angle.

IMHOFF et al. (2001), SEVERIANO et al. (2007) and FRANCO (2010) measured soil resistance to penetration with a penetrometer equipped with a load cell of $20 \mathrm{~kg}$ and a metal rod with $6 \mathrm{~mm}$ diameter (ending in a cone with an angle of penetration of $60^{\circ}$ and a BAC of $12.56 \mathrm{~mm}^{2}$ ). The penetration velocity used by the authors was $0.1667 \mathrm{~mm} \mathrm{~s}^{-1}$.

SERAFIM et al. (2008) developed a bench top penetrometer with a penetration rod $100 \mathrm{~mm}$ in length, $4 \mathrm{~mm}$ in diameter, and cone angle of $60^{\circ}$. The displacement velocity of the device could be adjusted in the range from 0.0833 to $0.5 \mathrm{~mm} \mathrm{~s}^{-1}$.

The standard test for resistance to field penetration established by the American Society of Agricultural and Biological Engineers - ASABE (ASABE, 2006), which is the most used in agricultural work in Brazil, determines that the field test must be conducted with constant velocity of $30 \mathrm{~mm} \mathrm{~s}^{-1}$ using a cone with base area equals to $129.28 \mathrm{~mm}^{2}$. However, what is observed in literature is that these values are not adopted by Brazilian researchers when it comes to bench top penetrometers. This may difficult the comparison of results obtained in laboratories with those from the field tests, if considered the possibility of different values of resistance when there are variations in the penetration rod (BAC and cone angle), as well as the velocity of the penetration test.

Given the above, the present study aimed to develop an automated bench top electronic penetrometer that allows penetrometry testing with high acquisition rate, different advance velocities, and different BAC; allowing laboratory tests in conditions similar and to the ones used in the field.

\section{MATERIAL AND METHODS}

This study was performed at the Laboratory of Agricultural Machinery and Engines (LAMAM), of the Faculty of Agronomy, Veterinary Medicine and Animal Science at the Federal University of Mato Grosso, located at Cuiabá city - state of Mato Grosso (MT), in Brazil.

The supporting structure of the automated bench top electronic penetrometer (ABEP) was made in 304 Stainless Steel, and sized so that the penetration probe of the equipment had a free lenght of $200 \mathrm{~mm}$. All components of the transmission system were sized and designed using the computational tool AutoCAD ${ }^{\circledR} 2004$ version. 
The drive system chosen for the ABEP was a Stepper Motor, model KML091F0, because it enables an accurate displacement of the probe into the soil. This motor has torque of $2.10 \mathrm{Nm}$ at rotation of 5 rev s-1. The system included a velocity reducer (worm gearbox, brand Hydromec (Italy), with a gear ratio of 1:7) to allow the penetrometer to operate at velocities up to $30 \mathrm{~mm} . \mathrm{s}^{-1}$ with sufficient torque to run tests of Soil Resistance to Penetration (SRP) of up to $6 \mathrm{MPa}$. The control of rotation and displacement of the stepper motor is performed by a firmware (driver model ST10-Plus) manufactured by Applied Motion Products (Canada). This firmware smoothes electronic torque, reduces noise and engine vibration, and protects against high voltage and high temperature to prevent damage in adverse conditions. It has a communication interface with the computer through the RS-232 port for configuration and set up using the manufacturer provided software, where functions can be pre-set for later execution. The power supply, model PSK-3 (Brazil), was chosen for the stepper motor, with input voltage at 110 or $220 \mathrm{~V}$ and output voltage of $80 \mathrm{~V}$ and $7.0 \mathrm{~A}$.

The transmission system used to convert the rotational motion of the stepper motor to translational movement, for displacement of the probe (cone penetration), was the double nut ball screw model DFU-2005 (China). This mechanism was adopted to give greater precision and smoothness to the motion.

The design of the ABEP is open and allows variation was added in displacement velocity of the penetration cone, as well as the use of probes of different sizes. Six (6) different models of probes were made, and the largest BAC was equal to $129.28 \mathrm{~mm}^{2}$ (standard S313.3 FEB04 ASABE, 2006). The other probes had cones with base areas equal to $102.97 \mathrm{~mm}^{2}, 82.36 \mathrm{~mm}^{2}$, $52.94 \mathrm{~mm}^{2}, 34.21 \mathrm{~mm}^{2}$, and $10.99 \mathrm{~mm}^{2}$, all with cone angle of $30^{\circ}$. Thus, to meet the range of possible tests that could be performed with the ABEP, without losing the resolution, three separate load cells (Alpha - Brazil) were selected as penetration force sensors, one of 981N (100kgf.), one of 490.5N (50 kgf.) and another of 196.2N (20kgf.).

For the protection of the equipment, a cooling system in order to maintain the temperature of the components (transformer, driver, stepper motor and reducer) within the adequate range for operation of these components (maximum $60^{\circ} \mathrm{C}$ ).

After the assembly of the equipment, it was necessary to configure two softwares: the $Q$ Programmer $^{\mathrm{TM}}$ and the Quantum Assistant ${ }^{\mathrm{X}}$. The first is the communication between the driver ST10-Plus and the computer, which configures the driver and controls the operation of the stepper motor as needed. The second software makes the communication between the computer and the module MX840A of the brand Hottinger Baldwin Messtechnik (Germany), which records the data of time and strength obtained in the tests. The choice of the module MX840A was due to its read and capture speed that can reach $19,000 \mathrm{~Hz}$, which allows for high resolution data regarding the phenomena that occur during a test of penetration. This module is connected to the load cell via connection D-SUB-15HD, which reads and records the data from the load cell and then sends to the computer via Quantum Assistant ${ }^{\mathrm{X}}$. The collected data can be stored and subsequently treated with other software, such as Microsoft Excel.

The validation of the ABEP was performed by checking if the equipment followed the preestablished velocities and travel distances; while the performance of the ABEP was assesed in a second test at different velocities and cone size. For the validation test, two parameters were entered into the ST10-Plus: velocity and distance to be travelled by the probe. The highest velocity (30mm $\mathrm{s}-1$ ) was tested in combination with a $75 \mathrm{~mm}$ distance to be travelled by the probe; while the lowest velocity $(0.1 \mathrm{~mm} \mathrm{~s}-1)$ was combined with a $6 \mathrm{~mm}$ distance. While the ABEP was performing the tests, the MX840A (resolution of $0.0008 \mathrm{~s}$ ) recorded the time required for the probe to travel the pre established distance. After the tests were performed by the ABEP, the distance travelled by the probe was also measured by a digital pachymeter (resolution of $0.01 \mathrm{~mm}$ ). Using the distances and time measured by the pachymeter and MX840A, respectively, the velocity and travel distance of the probe were calculated and used to validate the equipment. The performance test involved the 
assessment of soil resistance to penetration with two cones of different base areas (C1 = 11,05 $\mathrm{mm}^{2}$ and C2 $=34,21 \mathrm{~mm}^{2}$ ), and two velocities of cone penetration (V1 $=10 \mathrm{~mm} \mathrm{~min}-1$ or $0.1667 \mathrm{~mm} \mathrm{~s}-1$ and V2 $=30 \mathrm{~mm} \mathrm{~s}-1$ ). The V1 was chosen because it is the velocity used in most studies developed with bench top penetrometers (GELAIN et al. (2011); BERGAMIN et al. (2010); PACHECO \& CATALICE (2011); SERAFIM et al. (2008); BEUTLER et al. (2007). The V2 corresponds to the standard velocity established by the ASABE-ASAE, 1998, for field tests. For this test 32 undeformed samples (50mm diameter, $50 \mathrm{~mm}$ height) of a typical Dystrophic Red Latosol soil were randomly collected, using a Kopeck sampler. The moisture of the soil samples used for the tests was measured as $0.28 \mathrm{~kg} \mathrm{~kg}^{-1}$.

The force data were collected at a frequency of $5 \mathrm{~Hz}$ for the velocity of $0.16667 \mathrm{~mm} \mathrm{~s}^{-1}$ and $600 \mathrm{~Hz}$ for the velocity of $30 \mathrm{~mm} \mathrm{~s}^{-1}$. The signal values collected in $\mathrm{mV} \mathrm{V}^{-1}$ were converted to Newtons (N) using the calibration equation of the load cell for the test, which was obtained by a torque arm and standard weights of E1 and M1 class. Equation 1 was the one determined for the cell of nominal load of $196.2 \mathrm{~N}$, used in the tests.

$$
Y=-0,0091 x-0,0124 \quad\left(\mathrm{R}^{2}=0.9999\right)
$$

in which,

$\mathrm{y}=$ weight, in Newton, and

$\mathrm{x}=$ reading, in $\mathrm{mV} \mathrm{V}^{-1}$.

The distance travelled by the cone inside of the sample (depth) was determined by the time recorded during the test, in seconds, and the average velocity pre-determined for each test, considering the frequency of data acquisition of each test. The values of soil resistance to penetration, in $\mathrm{MPa}$, were obtained based on the force data collected and the base area of the corresponding cone.

The data were evaluated by analysis of variance and average comparison test (Tukey, $\mathrm{p}$ $<0.05)$, using the statistical application MINITAB ${ }^{\circledR}$ Release 14.1, to check for differences between the cones and the velocities used in the tests.

\section{RESULTS AND DISCUSSION}

The assembly of the ABEP was simple, requiring basic knowledge in electronics for the connection of electrical and electronic components. The transmission system and structure of the ABEP were designed using the computational tool AutoCAD ${ }^{\circledR} 2004$; they were scaled to allow the probe to penetrate up to $200 \mathrm{~mm}$ into the sample and made of 304 Stainless Steel.

The arrangement of the ABEP components followed a logical criterion, in order to accommodate all the parts in the shortest space possible, while allowing for enough air flow, so the hot areas would not compromise the operation of the ABEP. On the upper portion of the structure a power transformer was attached to provide the needed voltage of $80 \mathrm{~V}$ and $7.0 \mathrm{~A}$ for the stepper motor and the driver ST10-Plus, which were also attached to the upper portion of the structure. The stepper motor and the velocity reducer were mounted to the upper extremity of the spindle, vertically positioned, through a superior roller bearing fixed to the structure by a flange. The lower portion superior of the spindle was fixed by an inferior roller bearing, which was attached to a stainless steel tube, which was attached to the superior base of the ABEP through a flange. Thus, the spindle and the double nut were sealed inside the tube, allowing for lubrication by oil immersion. The travel distance of the double nut was limited by the superior and inferior bearings.

The double nut was then connected to an external bearing by four rods, that passed beyond the inferior bearing, where 4 retainers prevented leakage of lubricating oil. In the external bearing there is a central thread where one could install one of the three load cells chosen to equip the ABEP, which can be easily and quickly exchanged. Finally, in the load cell, there is also a coupling that allows the attachment of the rods with their penetration cones. 
To prevent equipment damage, a fixed snap-action switch was installed at the superior and inferior portions of the structure. They were linked to the driver ST10-Plus, which instantaneously interrupts the execution of the stepper motor when triggered. The cooling system of the ABEP was made of a stainless steel box and two axial fans, model FZY 12038, aiming to create a current of cooling air in the components (transformer, driver, stepper motor and reducer). A fan was attached on the front side for air intake, and the other was installed in the rear to exhaust the internal air. The box, which also serves as protection for the components that are part of the upper structure of the equipment, contains on the front an on/off switch, and 3 "LEDs" indicating connected device, activation of superior snap-action switch, and inferior snap-action switch. On the side of the box, there is a RJ 11 connection that allows communication between the driver ST10-Plus and the computer for programming and execution of tests.

To complete the assembly of the ABEP (Figure 01), a device was attached in order to accommodate the soil samples for the penetrometry tests, so the cone penetrates the center of the sample. The base was constructed to enable the use of samples with diameters of $50 \mathrm{~mm}, 75 \mathrm{~mm}$, $100 \mathrm{~mm}$ and $150 \mathrm{~mm}$.

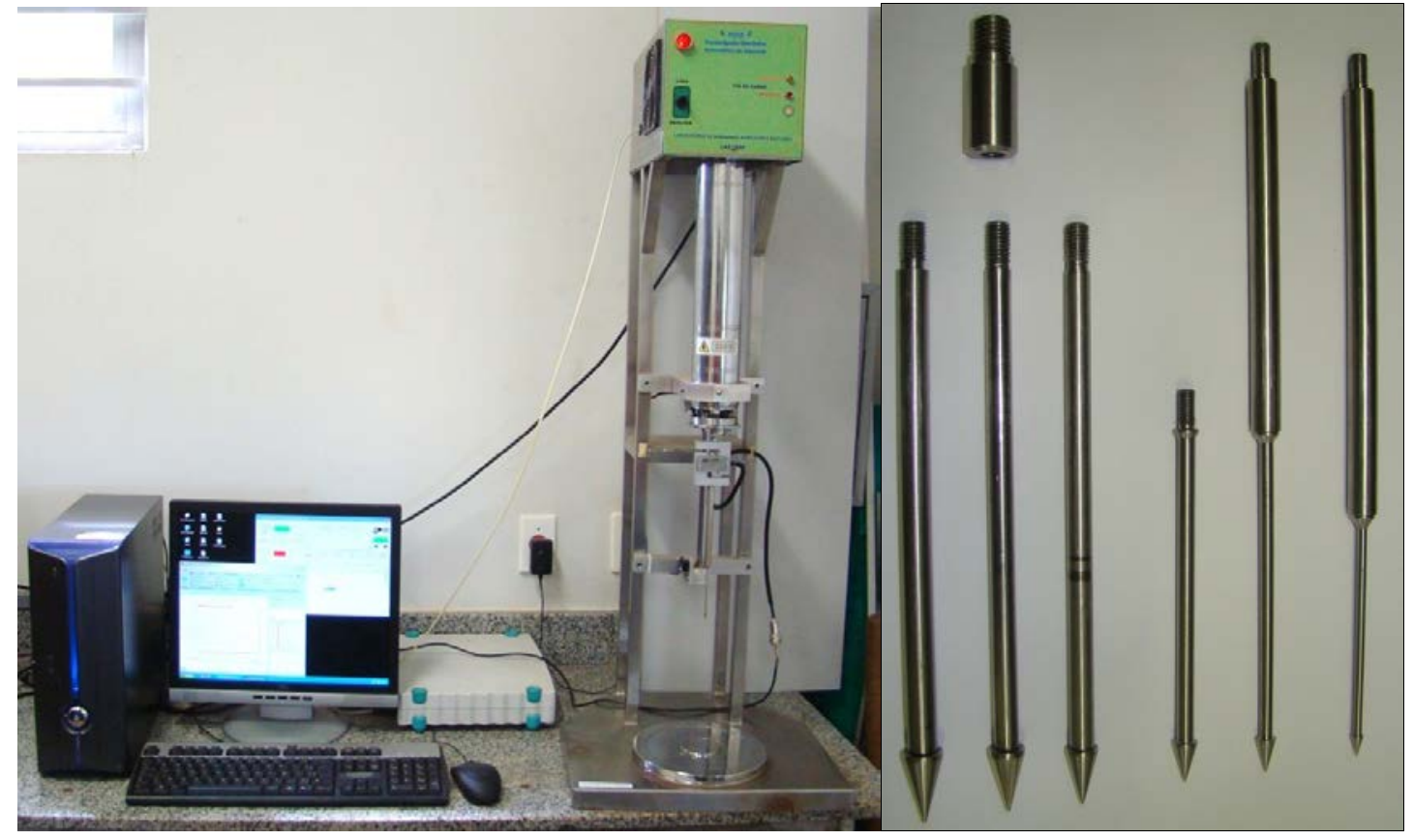

FIGURE 1. Automated bench top electronic penetrometer (ABEP) and penetration cones.

The implementation of ABEP was possible by the writting of routines that are loaded into the $\mathrm{Q}$ Programmer ${ }^{\mathrm{TM}}$ to control the stepper motor, the advance velocity of the cone and its travel distance. Thus, several routines were created to perform tests with different velocities and travel distances of the cones. Furthermore, in the created routines features were included to allow zeroing the position of the cone and the cone return to the starting position if a snap-action switch was activated. Thus, the ABEP proved itself versatile, reliable and simple to operate. Besides the prepared routines, the user could also create others that meet particular conditions of testing, through a tutorial that is in the user manual of the equipment.

The results obtained by the validation tests at $30 \mathrm{~mm} \mathrm{~s}^{-1}$ and $0.1 \mathrm{~mm} \mathrm{~s}^{-1}$ velocities, and the travel distances by the probe of $75 \mathrm{~mm}$ and $6.0 \mathrm{~mm}$, respectively, are shown in Table 1 . The average values obtained revealed that the developed ABEP had efficient control of velocity and distance to be travelled by the cone because at high velocity $\left(30 \mathrm{~mm} \mathrm{~s}^{-1}\right)$ the errors were of only $1.3 \%$ for velocity and $0.7 \%$ for travel distance; while at the low velocity $\left(0.1 \mathrm{~mm} \mathrm{~s}^{-1}\right)$ the errors were, respectively, $1 \%$ and $0.9 \%$ for velocity and travel distance. These errors include, besides the equipment error, reading errors, because even performing with a pachymeter of $0.01 \mathrm{~mm}$ resolution, measurement errors can occur. 
TABLE 1. Velocities and travel distances obtained in tests performed at pre determined velocities of $30 \mathrm{~mm} \mathrm{~s}^{-1}$ and $0.1 \mathrm{~mm} \mathrm{~s}^{-1}$.

\begin{tabular}{|c|c|c|c|c|c|c|c|}
\hline \multirow{2}{*}{$\begin{array}{c}\text { Anticipate } \\
\text { d } \\
\text { travel } \\
\text { distance }\end{array}$} & \multirow{2}{*}{$\begin{array}{c}\text { Anticipated } \\
\text { Velocity }\end{array}$} & \multicolumn{2}{|c|}{$\begin{array}{c}\text { Measured average } \\
\text { values }\end{array}$} & \multicolumn{2}{|c|}{$\begin{array}{c}\text { Standard } \\
\text { deviation } \\
(\mathrm{SD}) \\
\end{array}$} & \multicolumn{2}{|c|}{$\begin{array}{c}\text { Coeficient of } \\
\text { Variation } \\
\text { CV (\%) }\end{array}$} \\
\hline & & $\begin{array}{c}\text { Travel } \\
\text { distance } \\
\text { (TD) }\end{array}$ & $\begin{array}{l}\text { Velocit } \\
\text { y (Vel) }\end{array}$ & TD & Vel & Dis & Vel \\
\hline $75 \mathrm{~mm}$ & $30 \mathrm{~mm} \mathrm{~s}^{-1}$ & 75.53 & 30.400 & 0.870 & 0.900 & 1.15 & 2.96 \\
\hline $6 \mathrm{~mm}$ & $0.1 \mathrm{~mm} \mathrm{~s}^{-1}$ & 5.88 & 0.099 & 0.017 & 0.005 & 0.29 & 0.50 \\
\hline
\end{tabular}

The equipment proved to be reliable through the tests, showing no failure during the testing period and allowed the visualization of the obtained data in a graph form, in real time, even when programmed to work at a velocity of $30 \mathrm{~mm} \mathrm{~s}^{-1}$. The ability to perform tests at $30 \mathrm{~mm} \mathrm{~s}^{-1}$ allows the performance of bench top tests in a laboratory environment under the same conditions as field surveys, according to the ASABE standard norm. This ABEP can perform tests at an acquisition rate of up to $19,000 \mathrm{~Hz}$, which associated with the ability to precisely control velocity, a rotational movement angle of $1.8^{\circ}$ per pulse, and the use of cones with different base areas, turns this equipment into a powerful tool for penetrometry tests. Its use could range from data collection to routine tests to their use in advanced studies of disruption of soil under laboratory conditions.

The average results of the performance tests with cones and velocities chosen, are shown in Figure 2. In this figure, the data obtained for the central portion of the volumetric circle can be observed, when the transient regions of the circles (i.e. initial $20 \mathrm{~mm}$ and final $10 \mathrm{~mm}$ ) are eliminated. The average values of SRP obtained for the smaller cone (BAC of $11.05 \mathrm{mmm}^{2}$ ) at the velocity of 30 $\mathrm{mm} \mathrm{s}^{-1}$ (V2C1 in Figure 2), stand out from the others throughout the assessed profile. The SRP curves obtained for the two evaluated cones presented a slight overlap of their confidence interval for the lowest velocity of the test $\left(0.1667 \mathrm{~mm} \mathrm{~s}^{-1}\right)$.

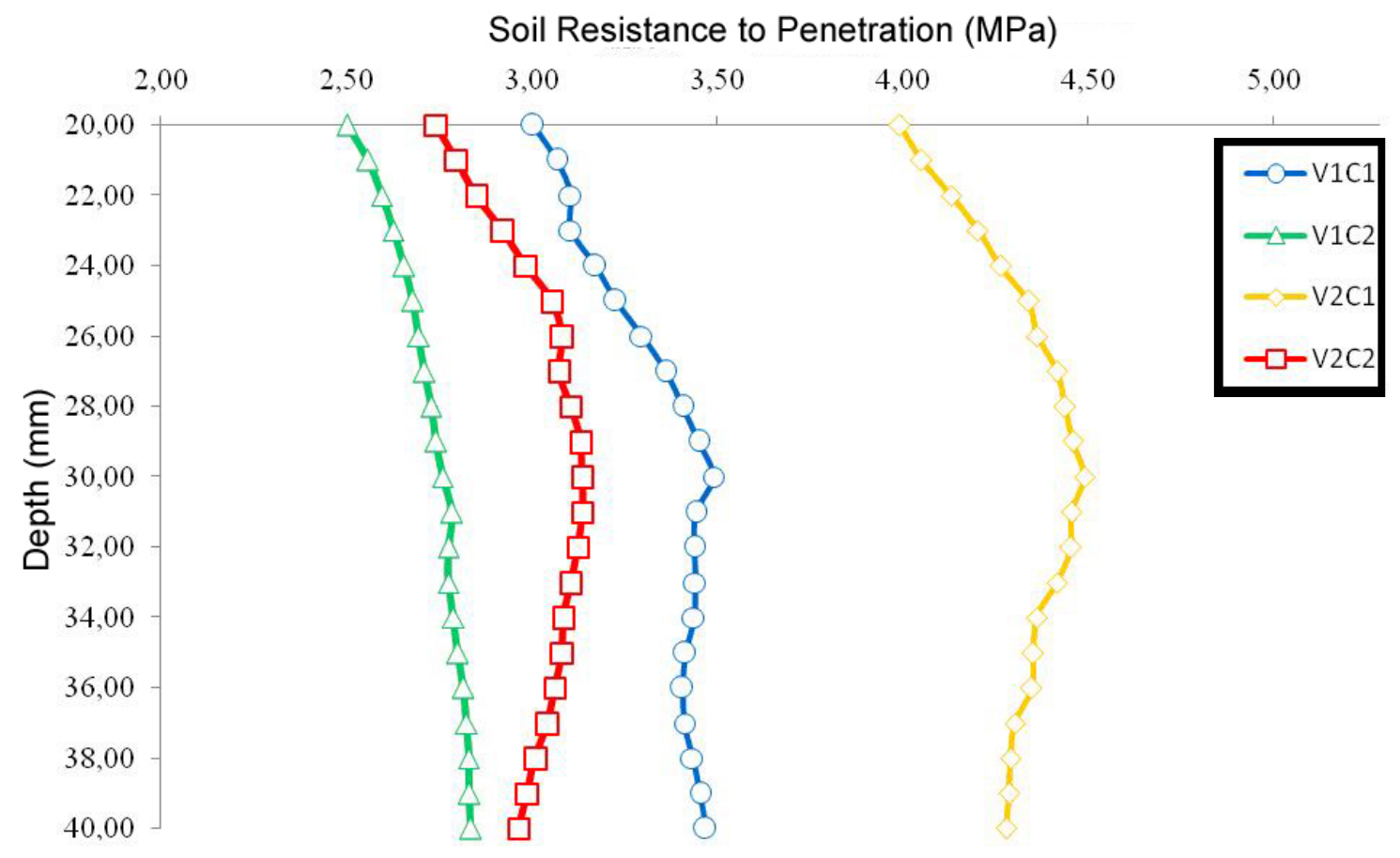

FIGURE 2. Average of Soil Resistance to Penetration (cone index) as a function of depth for the velocities of $0.1667 \mathrm{~mm} \mathrm{~s}^{-1}$ (V1) and $30 \mathrm{~mm} \mathrm{~s}^{-1}$ (V2), combined with cones of base area of $11.05 \mathrm{~mm}^{2}$ (C1) and $34.21 \mathrm{~mm}^{2}$ (C2) $(\mathrm{P}<0.1$ by Student's $t$ test). 
Table 2 shows the average values of Cone index (CI) obtained for the two types of cones and penetration velocities in the range of 20 to $40 \mathrm{~mm}$ of depth. The response obtained for the CI, due to the base area of the cone, was inverse and higher for the cone of smaller diameter, agreeing with the results obtained by SPEKTOR (1981). The penetration velocity also affected the CI, but the response was directly proportional, i.e., the highest value of CI was recorded for the highest velocity test, similar tendency was also obtained by SILVA (1999), working with a hydraulic penetrometer.

Both the velocity and the BAC showed interaction since at the velocity of $30 \mathrm{~mm} \mathrm{~s}^{-1}$, the CI was higher when using the cone with BAC of $11.05 \mathrm{~mm}^{2}$ compared to that obtained for the cone with BAC of $34.21 \mathrm{~mm}^{2}$. As for the velocity of $0.1667 \mathrm{~mm} \mathrm{~s}^{-1}$, the cone size did not affect the values of CI. The results obtained for the interaction between velocity and BAC suggest the need for future studies involving these two variables, seeking to minimize its effects on the CI for the purpose of standardization of penetrometry tests in bench tops (laboratory).

TABLE 2. Averages of Cone Index (CI) for the velocities of $0.1667 \mathrm{~mm} \mathrm{~s}^{-1}$ (V1) and 30mm s $\mathrm{m}^{-1}$ (V2) combined with cones of BAC of $11.05 \mathrm{~mm}^{2}$ (C1) and $34.21 \mathrm{~mm}^{2}$ (C2)

\begin{tabular}{lccc}
\hline \multirow{2}{*}{ Cones } & \multicolumn{2}{c}{ Velocities } & \multirow{2}{*}{ Averages } \\
\cline { 2 - 3 } & $\mathrm{V} 1\left(0.1667 \mathrm{~mm} \mathrm{~s}^{-1}\right)$ & $\mathrm{V} 2\left(30 \mathrm{~m} \mathrm{~s}^{-1}\right)$ & $3.71 \mathrm{a}$ \\
$\mathrm{C} 1\left(11.05 \mathrm{~mm}^{2}\right)$ & $3.35 \mathrm{aB}$ & $4.12 \mathrm{aA}$ & $2.77 \mathrm{~b}$ \\
$\mathrm{C} 2\left(34.21 \mathrm{~mm}^{2}\right)$ & $2.74 \mathrm{Aa}$ & $2.81 \mathrm{bA}$ &
\end{tabular}

*Averages followed by the same small letter in the column or capital letter in the line, for the same variable, do not differ by the $\mathrm{F}$ test $(\mathrm{p}<0.05)$.

The influence of the base area of the cone in the values of CI is of concern, because there are no criteria or standards established for conducting this type of test, and researchers have recently used cones of different angles and base areas (GELAIN et al., 2011; PACHECO, 2010; FRANCO, 2010, and BEUTLER et al., 2007). The velocity of penetration also influenced the obtained CI, as it was observed from the results presented in Table 2. The recent literature regarding penetrometry shows that researchers have adopted different velocities, as in CARMO et al. (2011), GELAIN et al. (2011), BERGAMIN et al. (2010), PETEAN et al. (2010) and SERAFIM et al. (2008), without an apparent criterion.

Given these results and the diversity of procedures that have been adopted in penetrometry tests, it becomes imperative the need to conduct further and more comprehensive studies in this area. Future studies should determine the rules of procedure in CI tests for agricultural purposes to be performed by bench top penetrometers to accomplish this, versatile penetrometers with a high degree of reliability as the ABEP described here will be essential.

\section{CONCLUSIONS}

After the performed tests and the analysis of results, it was concluded that the automated bench top electronic penetrometer - ABEP:

- It is versatile, with a total cone travel distance of up to $200 \mathrm{~mm}$, the ability to handle samples with diameters from $50 \mathrm{~mm}$ to $150 \mathrm{~mm}$, and capability of performing tests with cone velocities from $0.1 \mathrm{~mm} \mathrm{~s}^{-1}$ to $30 \mathrm{~mm} \mathrm{~s}^{-1}$.

- Allows running tests with all the suggested cone sizes BAC (from $10.99 \mathrm{~mm}^{2}$ to $\left.129.28 \mathrm{~mm}^{2}\right)$ with high resolution $(19,600 \mathrm{~Hz})$ and reliability in data collection.

- Performed tests in conditions similar to the field, i.e., with velocity of $30 \mathrm{~mm} \mathrm{~s}^{-1}$ and BAC of 129.28mm² (standard ASAE S 313,2). 


\section{ACKNOWLEDGEMENTS}

To the Foundation for the Support of Research in the State of Mato Grosso (Fundação de Amparo a Pesquisa do Estado do Mato Grosso - FAPEMAT), for financial assistance in the development of the research project.

\section{REFERENCES}

ASABE. American Society of Agricultural and Biological Engineers. ASAE: S313.3 FEB04 Soil cone penetrometer. St. Joseph: ASABE Standards, 2006. p.902-904.

BERGAMIN, A.C.; VITORINO, A.C.T.; FRANCHINI, J.C.; SOUZA, C.M.A.; SOUZA F.R. Compactação em um Latossolo Vermelho Distroférrico e suas relações com o crescimento radicular do milho. Revista Brasileira de Ciência do Solo, Viçosa-MG, v. 34, p. 681-691, 2010.

BEUTLER, A.N; CENTURION, J.F.; SILVA, A.P. Comparação de penetrômetros na avaliação da compactação de latossolos. Engenharia Agrícola, Jaboticabal, v.27, n.1, p.146-151, jan./abr. 2007.

CARMO, D.L.; NANNETTI, D.C.; DIAS JÚNIOR, M.S.; SANTO, D.J.E.; NANNETTI, A.N.; LACERDA, T.M. Propriedades físicas de um Latossolo Vermelho-Amarelo cultivado com cafeeiro em três sistemas de manejo no sul de minas gerais. Revista Brasileira de Ciência do Solo, ViçosaMG, v. 35, p. 991-998, 2011.

COLLARES, G.L.; REINERT, D.J.; REICHERT, J.M. KAISER, D.R. Qualidade física do solo na produtividade da cultura do feijoeiro num Argissolo. Pesquisa Agropecuária Brasileira, Brasília, v. 41, p. 1663-1674, 2006.

COLLARES, G.L.; REINERT, D.J.; REICHERT, J.M. KAISER, D.R. Compactação de um Latossolo induzida pelo tráfego de máquinas e sua relação com o crescimento e produtividade de feijão e trigo. Revista Brasileira de Ciência do Solo, Viçosa-MG, v. 32, p. 933- 942, 2008.

FRANCO, A.M.P. Erosão em entressulcos e qualidade física de solos construídos após mineração de carvão. 2010. 108 f. Tese (Doutorado) - Universidade Federal do Rio Grande do Sul, Porto Alegre, 2010.

GELAIN, N.S.; SILVA, B.R.; FERRIGOLO, B.Z.; GUBIANI, P.I.; REINERT, D.J.; REICHERT J.M. Densidade e resistência do solo à penetração em função da qualidade das amostras. In: CONGRESSO BRASILEIRO DE CIÊNCIA DO SOLO, 33., 2011, Uberlândia. Anais... Disponível em < http://w3.ufsm.br/fisicadosolo/downloads/Producao_Resumos/XXXIII_4.pdf>. Acesso em: Out. 2011.

IMHOFF, S.; PIRES DA SILVA, A.; DIAS JUNIOR, M. DE S.; TORMENA, C. A. Quantificação de pressões críticas para o crescimento das plantas. Revista Brasileira de Ciência do Solo, ViçosaMG, v. 25, p. 11-18, 2001.

KLEIN, V.A.; CAMARA, R.K. Rendimento da soja e intervalo hídrico ótimo em Latossolo Vermelho sob plantio direto escarificado. Revista Brasileira de Ciência do Solo, Viçosa-MG, v. 31, p. 221-227, 2007.

PACHECO, E.P. Estudo da compressibilidade e qualidade de um Argissolo Amarelo cultivado com cana-de-açúcar nos Tabuleiros Costeiros de Alagoas. 2010. 106 f. Tese (Doutorado) Universidade Federal Rural de Pernambuco, Recife, 2010.

PACHECO, E.P.; CANTALICE, J.R.B. Compressibilidade, resistência a penetração e intervalo hídrico ótimo de um Argissolo Amarelo cultivado com cana-de-açúcar nos tabuleiros costeiros de alagoas Revista Brasileira de Ciência do Solo, Viçosa-MG, v. 35, p. 403-415, 2011.

PETEAN, L.P.; TORMENA, C.A.; ALVES, S.J. Intervalo hídrico ótimo de um Latossolo Vermelho Distroférrico sob plantio direto em sistema de integração lavoura-pecuária. Revista Brasileira de Ciência do Solo, Viçosa-MG, v. 34, p. 1515-1526, 2010. 
SERAFIM, M.E.; VITORINO, A.C.T.; SOUZA, C.M.A.; PRADO, E.D.; VENTURIN, J.C.; YAMAMOTO, N.T. Desenvolvimento de um penetrógrafo eletromecânico de bancada. Revista Ciências Técnicas Agropecuárias, v. 17, p. 61-65, 2008.

SEVERIANO, E.C.; OLIVEIRA, G.C.; DIAS JÚNIOR, M.S.; CASTRO, M.B.; SOARES, R.A.B. Alterações estruturais em um Latossolo e um Cambissolo submetidos à colheita mecanizada da cana-de-açúcar. IN: CONGRESSO BRASILEIRO DE CIÊNCIA DO SOLO, 31., 2007. Anais... Disponível em: < http://www6.ufrgs.br/cbcs/trabalhos/trabalhos/trab_8523-1417.pdf>. Acesso em: Out. 2011.

SILVA, M.L.L. Modelagem matemática na estimativa da densidade de um Latossolo Vermelho Escuro textura argilosa, pelo índice de cone. 1999. 161 f. Teses (Doutorado) - Universidade Estadual de Campinas, 1999.

SILVA, V.R. da. Propriedades físicas e hídricas em solos sob diferentes estados de compactação. 2003. 171 f. Tese (Doutorado) - Universidade Federal de Santa Maria, Santa Maria, 2003.

SPEKTOR, M. Principles of soil-tool interaction. Journal of Terramechanics, London, v. 18, n. 1, p. 51-65, 1981. 